\title{
Structure of debromo-carteramine $A$, a novel bromopyrrole alkaloid from the Mediterranean sponge Axinella verrucosa
}

\author{
Markus Haber, a,b Marianna Carbone, ${ }^{a}$ Micha Ilan,b and Margherita Gavagnina* \\ ${ }^{a}$ Istituto di Chimica Biomolecolare, CNR, Via Campi Flegrei 34, I 80078-Pozzuoli (Na), Italy \\ ${ }^{\mathrm{b}}$ Department of Zoology, Tel Aviv University, Tel Aviv 69978, Israel \\ E-mail: margherita.gavagnin@icb.cnr.it
}

\begin{abstract}
The butanol extract of the Mediterranean sponge Axinella verrucosa was fractionated via a bioactivity-guided procedure based on an antibacterial assay. This approach led to the isolation of the novel alkaloid debromo-carteramine A 2 co-occurring with known hymenidin 1, the main antibacterial agent of the extract, and related inactive carteramine A $\mathbf{3}$.
\end{abstract}

Keywords: Marine natural products, bromopyrrole alkaloids, sponge, antibacterial activity

\section{Introduction}

Marine sponges of genus Axinella are a well-known source of brominated pyrrole alkaloids. ${ }^{1-7}$ Historically, these compounds, which have been found only in the marine environment to date, have attracted the attention of natural product chemists because of their structural complexity. Today, the interest is sparked not only by the wide structural diversity, ranging from simple molecules like oroidin ${ }^{8,9}$ to complex structures like palau'amine ${ }^{10,11}$ and stylissadine $\mathrm{A}$ and $\mathrm{B},{ }^{12}$ but also by their organic synthesis, ${ }^{13}$ bio-synthesis, ${ }^{14}$ and pharmacological activities. ${ }^{6,7,15}$ Furthermore, these compounds have a chemo-ecological interest due to their role in chemically mediated interactions such as in the chemical defense against predators ${ }^{16,17}$ and fouling organisms. ${ }^{18-20}$ The crude extracts of different Axinella species have also been reported to inhibit the growth of several environmental bacteria. ${ }^{21}$

Using a bioassay-guided isolation approach, we have analyzed the butanol extract of a sample of $A$. verrucosa collected during the spring 2008 off Massa Lubrense, Bay of Naples. The extract showed strong antibacterial activity against the marine bacterium Lysinibacillus $\mathrm{sp}$. It was found that the main component of the extract, hymenidin 1 (Figure 1), previously isolated from Hymeniacidon sponge, ${ }^{22}$ was also the main compound responsible of the observed antimicrobial activity. Analysis of the fractions exhibiting a weak/moderate activity led to the isolation of a novel alkaloid of the palau'amine class, debromo-carteramine A 2 (Figure 1). Interestingly, the 
same fraction also contained the known related compound carteramine A 3 (Figure 1), recently isolated from Stylissa carteri $^{23}$ and identical with the compound named tetrabromostyloguanidine reported at the same time from Stylissa caribica. ${ }^{24}$ Carteramine A did not inhibit the bacterium of choice. In this paper, we report the isolation and structure elucidation of the novel compound 2.
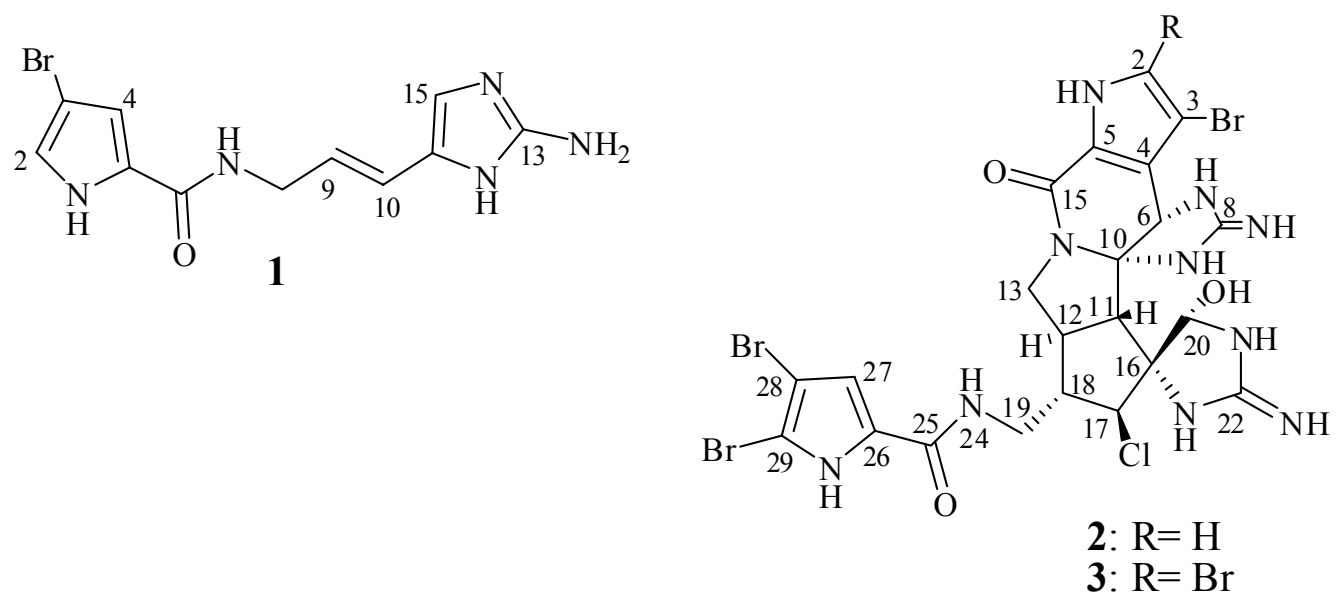

Figure 1. Structures of bromopyrrole alkaloids isolated from the sponge Axinella verrucosa.

\section{Results and Discussion}

An aliquot $(185 \mathrm{mg})$ of the butanolic soluble portion $(690 \mathrm{mg})$ of the acetone extract of the sponge (5.6 g, dry weight after extraction) was submitted to molecular exclusion chromatography (Sephadex $\mathrm{LH}-20, \mathrm{CHCl}_{3} / \mathrm{MeOH}, 1: 1$ ) to give two distinct sets of active fractions. The fraction eluted first contained pure hymenidin 1 whereas the second fraction was a mixture that was further purified by reverse-phase HPLC with a linear gradient system to give a pure active compound, debromo-carteramine A $(2,4.0 \mathrm{mg})$, and the inactive related carteramine A (3, $3.7 \mathrm{mg})$. Compounds $\mathbf{1}$ and $\mathbf{3}$ were identified by comparison of their spectroscopic data with those reported in the literature. ${ }^{22-24}$

Debromo-carteramine A 2 showed a sodiated-molecular peak at $\mathrm{m} / \mathrm{z} 746.9163$ in the HRESIMS spectrum, which indicated the molecular formula $\mathrm{C}_{22} \mathrm{H}_{22} \mathrm{ClBr}_{3} \mathrm{~N}_{10} \mathrm{O}_{3}$ differing from that of the co-occurring 3 in the presence of a hydrogen atom instead of a bromine. Compound $\mathbf{2}$ displayed in the ${ }^{13} \mathrm{C}$ NMR spectrum characteristic signals consistent with the presence of two guanidine moieties $\left(\delta_{C} 157.6\right.$ and 158.6), and two units of pyrrole-2-carboxylic acid amide exhibiting bromine substituents $\left[\delta_{C} 161.2(\mathrm{~s}, \mathrm{C}-25), 128.1\right.$ (s, C-26) 114.7 (d, C-27), 99.0 (s, C28), 106.7 (s, C-29) and 152.8 (s, C-15), 126.1 (d, C-2), 122.0 (s, C-5), 121.5 (s, C-4), 94.9 (s, C3). 
Table 1. ${ }^{1} \mathrm{H}$ and ${ }^{13} \mathrm{C}$ NMR spectral data ${ }^{\mathrm{a}}$ in $\mathrm{CD}_{3} \mathrm{OD}$ of debromo-carteramine A 2

\begin{tabular}{ccccc}
\hline Position & $\delta_{\mathrm{H}}($ mult,$J$ in Hz) & $\delta_{\mathrm{C}}$ & $\mathrm{m}$ & $\mathrm{HMBC}$ \\
\hline 2 & $7.12(\mathrm{~s})$ & 126.1 & $\mathrm{~d}$ & - \\
3 & - & 94.9 & $\mathrm{~s}$ & $\mathrm{H}-2$ \\
4 & - & 121.5 & $\mathrm{~s}$ & - \\
5 & - & 122.0 & $\mathrm{~s}$ & $\mathrm{H}-6, \mathrm{H}-2$ \\
6 & $5.79(\mathrm{~s})$ & 55.8 & $\mathrm{~d}$ & - \\
8 & - & 157.6 & & $\mathrm{H}-6$ \\
10 & - & 83.1 & $\mathrm{~s}$ & $\mathrm{H}-6$ \\
11 & $2.93(\mathrm{~d}, 15)$ & 57.9 & $\mathrm{~d}$ & $\mathrm{H}-13 \mathrm{a}, \mathrm{H}-6$ \\
12 & $2.59(\mathrm{~m})$ & 42.5 & $\mathrm{~d}$ & $\mathrm{H}-13 \mathrm{~b}$ \\
13 & $3.17(\mathrm{app} . \mathrm{t}, 10)$ & 47.2 & $\mathrm{t}$ & - \\
& $3.97(\mathrm{dd}, 8,10)$ & & & \\
15 & - & 152.8 & $\mathrm{~s}$ & - \\
16 & - & 71.9 & $\mathrm{~s}$ & $\mathrm{H}-17 ; \mathrm{H}-11$ \\
17 & $4.32(\mathrm{~d}, 9)$ & 74.5 & $\mathrm{~d}$ & $\mathrm{H}-20 ; \mathrm{H}-19 \mathrm{a}$ \\
18 & $2.32(\mathrm{~m})$ & 51.3 & $\mathrm{~d}$ & $\mathrm{H}-17$ \\
19 & $3.52(\mathrm{br} \mathrm{dd}, 8,14)$ & 40.4 & $\mathrm{t}$ & $\mathrm{H}-17$ \\
& $3.75(\mathrm{~m})$ & & & \\
20 & $5.98(\mathrm{~s})$ & 84.1 & $\mathrm{~d}$ & $\mathrm{H}-17, \mathrm{H}-11$ \\
22 & - & 158.6 & $\mathrm{~s}$ & $\mathrm{H}-20$ \\
25 & - & 161.2 & $\mathrm{~s}$ & $\mathrm{H}-19 \mathrm{a}$ \\
26 & - & 128.1 & $\mathrm{~s}$ & - \\
27 & $6.87(\mathrm{~s})$ & 114.7 & $\mathrm{~d}$ & - \\
28 & - & 99.0 & $\mathrm{~s}$ & - \\
29 & - & 106.7 & $\mathrm{~s}$ & $\mathrm{H}-27$ \\
\hline
\end{tabular}

${ }^{a}$ Assignments made by ${ }^{1} \mathrm{H}-{ }^{1} \mathrm{H}$ COSY, HSQC and $\operatorname{HMBC}(J=10 \mathrm{~Hz})$ experiments.

In the ${ }^{1} \mathrm{H}$ NMR spectrum of 2 , an additional $1 \mathrm{H}$ singlet at $\delta 7.12(\mathrm{H}-2)$ was present with respect to 3 whereas the remaining part of the spectrum was almost identical. This signal was attributed to an isolated proton in the $\alpha$-position of a pyrrole ring thus indicating, in agreement with the molecular formula, that 2 lacked the bromine substituent at C-2 with respect to 3 . Further evidence was obtained from the ${ }^{13} \mathrm{C}$ NMR spectrum of 2 containing the $\mathrm{CH} \mathrm{sp}^{2}$ signal in the place of a $\mathrm{C} \mathrm{sp}^{2}$ signal (C-2). The presence of the chlorinated 7-azabicyclo [3.3.0.]octane ring system characterizing all members of the palau'amine class was also evident by analysis of the ${ }^{1} \mathrm{H}-{ }^{1} \mathrm{H}$ COSY spectrum. In fact the typical spin-system from $\mathrm{H}_{2}-13$ to $\mathrm{H}_{2}-19$ was easily detected. Analysis of 2D-NMR experiments $\left({ }^{1} \mathrm{H}-{ }^{1} \mathrm{H}\right.$ COSY, HSQC, and HMBC) allowed complete proton and carbon assignments as reported in Table 1 and confirmed that 2 was the 2-debromoderivative of carteramine $\mathrm{A}^{23}$ (三 tetrabromostyloguanidine). ${ }^{24}$ 
The relative stereochemistry of the eight chiral centres of $\mathbf{2}$ was suggested to be the same as 3 by comparison of their ${ }^{13} \mathrm{C}-\mathrm{NMR}$ data ${ }^{23}$ and was further supported by analysis of a series of NOE difference and NOESY experiments (Figure 2) recorded in $\mathrm{CD}_{3} \mathrm{OD}$ and $d_{6}$-DMSO, respectively. Analogous to the data reported for carteramine $\mathrm{A},{ }^{23}$ steric effects were observed for compound 2 between H-11 and both H-6 and H-20 according to the reported stereochemistry for both cyclic guanidine moieties. The absence of NOE interactions between $\mathrm{H}-11$ and $\mathrm{H}-12$ was in agreement with the trans-11,12-junction of the 7-azabicyclo[3.3.0.]octane ring, analogous to carteramine A. Diagnostic NOE effects were observed between H-12 and H-17, H-11 and H-18, and $20-\mathrm{OH}$ and both $\mathrm{H}-6$ and $\mathrm{H}-11$ that inferred the relative configuration at $\mathrm{C}-17, \mathrm{C}-18$, and C20 , respectively.

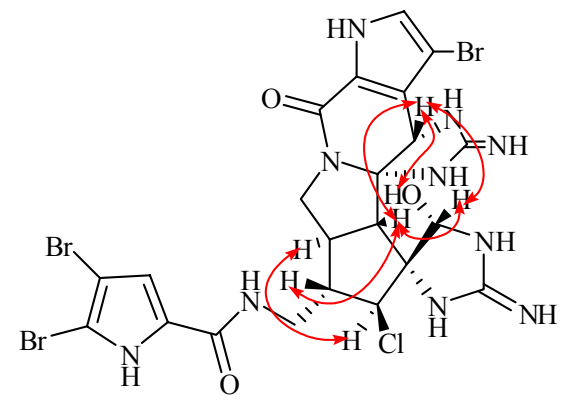

Figure 2. Significant NOE effects in debromo-carteramine A (2) by NOE difference and NOESY experiments.

Thus 2-debromo-carteramine A 2 exhibited the same relative configuration as carteramine $\mathrm{A}^{23}$ (三 tetrabromostyloguanidine), ${ }^{24}$ the stereochemistry of which was determined by NOESY analysis ${ }^{26}$ and computational methods, ${ }^{24}$ and differed from those reported for palau'amine and related compounds. ${ }^{10,11}$ However, in both these recent papers ${ }^{23,24}$ the relative configuration of palau'amine congeners was suggested to need revision.

Compounds $\mathbf{1}$ and $\mathbf{2}$ showed activity against the environmental marine bacterium Lysinibacillus sp. ESY 9 (GenBank accession no. GU059941) in the disc diffusion assay with an inhibition zone diameter of $12.5 \mathrm{~mm}$ at a concentration of $100 \mu \mathrm{g} / \mathrm{disc}$ and of $8 \mathrm{~mm}$ at a concentration of $200 \mu \mathrm{g} / \mathrm{disc}$, respectively. It is interesting to note that co-occurring carteramine A (3) was found to be inactive in the same test suggesting that free C-2 position is an essential requirement for this activity. 


\section{Experimental Section}

General. Optical rotations were measured on a JASCO DIP 370 digital polarimeter. The UV spectra were recorded on JASCO 710 spectropolarimeter. ${ }^{1} \mathrm{H}$ and ${ }^{13} \mathrm{C}$ NMR spectra were recorded on DRX 600, AVANCE 400, and DPX $300 \mathrm{MHz}$ Bruker spectrometers in $\mathrm{CD}_{3} \mathrm{OD}$ and in $d_{6}$-DMSO, with chemical shifts reported in ppm referred to $\mathrm{CH}_{3} \mathrm{OH}(\delta 3.34$ for proton and $\delta$ 49.9 for carbon) and to DMSO ( $\delta 2.54$ for proton and $\delta 40.5$ for carbon), respectively, as internal standards. ESIMS and HRESIMS were measured on a Micromass Q-TOF Micro ${ }^{\mathrm{TM}}$ coupled with a HPLC Waters Alliance 2695. The instrument was calibrated by using a PEG mixture from 200 to $1000 \mathrm{MW}$ (resolution specification $5000 \mathrm{FWHM}$, deviation $<5 \mathrm{ppm}$ RMS in presence of a known lock mass). Silica gel and exclusion chromatography were performed using precoated Merck $\mathrm{F}_{254}$ plates and Sephadex ${ }^{\mathrm{TM}}$ LH-20 (Amersham Biosciences), respectively. HPLC purifications were carried out on a Thermo Electron chromatograph coupled with P4000 pumps and a UV2000 double wavelength detector.

\section{Collection and extraction of the animal material}

Specimens of A. verrucosa were collected by Scuba during the Spring 2008 off Massa Lubrense, Bay of Naples at $25 \mathrm{~m}$ depth. The biological material was immediately transferred to the ICB laboratory, where it was cleaned from epibionts, rinsed once and frozen at $-20{ }^{\circ} \mathrm{C}$, until its extraction.

The frozen material was cut into pieces of about $1 \mathrm{~cm}^{3}$ and extracted with acetone $(250 \mathrm{~mL} \times 3)$ under grinding and sonication. The three phases were combined after filtration and the organic solvent was removed under reduced pressure. The residual water was partitioned three times with $\mathrm{Et}_{2} \mathrm{O}$ and subsequently with $n$-butanol. The combined $\mathrm{Et}_{2} \mathrm{O}$ phases $(461 \mathrm{mg})$ and the $n$-butanol $(690 \mathrm{mg})$ phase were dried under reduced pressure to give the initial two extracts.

\section{Purification of compounds}

An aliquot of $n$-butanolic extract (185 mg) was fractionated on a Sephadex LH-20 column. The collected fractions were re-combined based on their TLC pattern resulting in 17 fractions. All fractions were tested for their antibacterial activity, observing two active fractions, A (72 $\mathrm{mg}$ ) and B $(9 \mathrm{mg})$, which were further analyzed by ${ }^{1} \mathrm{H}$ NMR. Fraction A contained compound 1 pure, whereas fraction $\mathrm{B}$ resulted a mixture, which was purified on reverse-phase HPLC (Phenomenex: Kromasil $5 \mu \mathrm{C} 18,250 \times 10 \mathrm{~mm}, 40 \mathrm{~min}$ gradient from $50 \%$ to $100 \% \mathrm{CH}_{3} \mathrm{OH}$ in $\mathrm{H}_{2} \mathrm{O}$ with $0.1 \%$ of TFA, flow $2 \mathrm{~mL} / \mathrm{min}$, UV detector) to obtain compounds 2 and 3 .

Compound 1. Light yellow powder; ${ }^{1} \mathrm{H} \mathrm{NMR}\left(\mathrm{CD}_{3} \mathrm{OD}, 400 \mathrm{MHz}\right) \delta 4.09\left(\mathrm{~d}, J=4 \mathrm{~Hz}, 2 \mathrm{H}, \mathrm{H}_{2}-\right.$ 8), 6.15 (dt, $J=4,16 \mathrm{~Hz}, 1 \mathrm{H}, \mathrm{H}-9), 6.33$ (d, $J=16 \mathrm{~Hz}, 1 \mathrm{H}, \mathrm{H}-10), 6.78$ (s, 1H, H-15), 6.85 (d, $J$ $=1 \mathrm{~Hz}, 1 \mathrm{H}, \mathrm{H}-4), 6.96(\mathrm{~d}, J=1 \mathrm{~Hz}, 1 \mathrm{H}, \mathrm{H}-2) ;{ }^{13} \mathrm{C} \mathrm{NMR}\left(\mathrm{CD}_{3} \mathrm{OD}, 300 \mathrm{MHz}\right) \delta 162.4(\mathrm{~s}, \mathrm{C}-6)$, 149.1 (s, C-13), 128.7 (d, C-9), 127.4 (s, C-5 or C-11), 127.3 (s, C-11 or C-5), 122.9 (d, C-2), 117.5 (d, C-10), 113.4 (d, C-4), 111.8 (d, C-15), 97.5 (s, C-3), 42.5 (t, C-8). ESIMS m/z (rel. intensity) $310 / 312(1: 1)[\mathrm{M}+\mathrm{H}]^{+}$. 
Compund 2. Light yellow powder; $[\alpha]_{\mathrm{D}}-9.0$ (c 0.2, $\left.\mathrm{MeOH}\right) ; \mathrm{UV}(\mathrm{MeOH}) \lambda_{\max } 277 \mathrm{~nm}$ $\left(\varepsilon\right.$ 13,400); ${ }^{1} \mathrm{H}$ NMR $\left(d_{6}\right.$-DMSO, $\left.600 \mathrm{MHz}\right) \delta 12.67$ (br s, 1H, H-1), 9.38 (s, 1H, H-21), 8.70 (s, 1H, H-23), 9.18 (s, 1H, H-9), 9.00 (s, 1H, H-7), 8.37 (t, J=6 Hz, 1H, H-24), 7.55 (d, J= 5 Hz, $1 \mathrm{H},-\mathrm{OH}), 7.22$ (d, J=2 Hz, 1H, H-2), 6.95 (s, 1H, H-27), 5.71 (d, J=5 Hz, 1H, H-20), 5.52 (s, $1 \mathrm{H}, \mathrm{H}-6), 4.28$ (d, $J=9,1 \mathrm{H}, \mathrm{H}-17), 3.76$ (dd, $J=8$ and $10 \mathrm{~Hz}, 1 \mathrm{H}, \mathrm{H}-13 \mathrm{a}), 3.52$ (m, 1H, H-19a), 3.32 (m, 1H, H-19b), 2.99 (dd, $J=10,10$ Hz, 1H, H-13b), 2.82 (d, $J=14$ Hz, 1H, H-11), 2.45 $(\mathrm{m}, 1 \mathrm{H}, \mathrm{H}-12), 2.11(\mathrm{~m}, 1 \mathrm{H}, \mathrm{H}-18)$. Selected ${ }^{13} \mathrm{C}$ NMR values $\left(d_{6}\right.$-DMSO, $\left.300 \mathrm{MHz}\right) \delta 124.7$ (d, C-2), 113.0 (d, C-26), 82.3 (d, C-20), 74.0 (d, C-17), 55.7 (d, C-11), 53.5 (d, C-6), 49.3 (d, C18), 44.6 (t, C-13), 40.6 (d, C-12), 39.1 (t, C-19). HRESIMS m/z $746.9163[\mathrm{M}+\mathrm{H}]^{+}$(calcd for $\left.\mathrm{C}_{22} \mathrm{H}_{23}{ }^{35} \mathrm{Cl}^{79} \mathrm{Br}_{3} \mathrm{~N}_{10} \mathrm{O}_{3}, \Delta-3.0\right)$.

Compound 3. Light yellow powder; $[\alpha]_{\mathrm{D}}-37.0\left(c\right.$ 0.1, MeOH), $[\alpha]_{\mathrm{D}}$ lit. $^{23}-42.0$ (c 1.26, MeOH); ${ }^{1} \mathrm{H}$ NMR $\left(\mathrm{CD}_{3} \mathrm{OD}, 600 \mathrm{MHz}\right) \delta 6.86(1 \mathrm{H}, \mathrm{s}, \mathrm{H}-27), 5.98(1 \mathrm{H}, \mathrm{s}, \mathrm{H}-20), 5.75(1 \mathrm{H}, \mathrm{s}, \mathrm{H}-6), 4.33$ $(1 \mathrm{H}, \mathrm{d}, J=9 \mathrm{~Hz}, \mathrm{H}-17), 3.97(1 \mathrm{H}, \mathrm{dd}, J=8$ and $10 \mathrm{~Hz}, \mathrm{H}-13 \mathrm{a}), 3.73(1 \mathrm{H}, \mathrm{dd}, J=4 \mathrm{and} 14 \mathrm{~Hz}$, $\mathrm{H}-19 \mathrm{a}), 3.52(1 \mathrm{H}, \mathrm{dd}, J=8$ and $14 \mathrm{~Hz}, \mathrm{H}-19 \mathrm{~b}), 3.16(1 \mathrm{H}, \mathrm{dd}, J=10$ and $10 \mathrm{~Hz}, \mathrm{H}-13 \mathrm{~b}), 2.93$ (1H, d, $J=14 \mathrm{~Hz}, \mathrm{H}-11), 2.57$ (1H, m, H-12), 2.31 (1H, m, H-18). ESIMS $m / z$ (rel. intensity) $825 / 827 / 829 / 831 / 833(2: 6: 10: 7: 4: 1)[\mathrm{M}+\mathrm{H}]^{+}$.

\section{Antibacterial assays}

Disc diffusion assays were performed using the environmental marine bacterium Lysinibacillus sp. strain ESY 9 (GenBank accession no. GU059941). The bacterium was isolated on LB plates (10 $\mathrm{g} \mathrm{L}^{-1}$ Tryptone, $5 \mathrm{~g} \mathrm{~L}^{-1}$ Yeast Extract, $5 \mathrm{~g} \mathrm{~L}^{-1} \mathrm{NaCl}, 15 \mathrm{~g} \mathrm{~L}^{-1}$ Bactoagar) from sediment collected at $30 \mathrm{~m}$ depth close to the sponge $A$. verrucosa at the reef in front of Sdot Yam, Israel. Test extracts were transferred to blank paper discs (diameter $6 \mathrm{~mm}$ ) and left until the solvent completely evaporated. For the assay $250 \mu \mathrm{L}$ of an overnight culture grown in liquid LB medium at $30^{\circ} \mathrm{C}$ were plated onto a LB plates until the surface was dry. The paper discs with the applied extracts were then transferred to the seeded plates. Plates were wrapped with Parafilm and incubated for one day at $30{ }^{\circ} \mathrm{C}$ after which the diameter of inhibition zones, visible as clear zones around the paper discs, was measured to the next half millimeter. Solvent controls were always run in parallel and never showed inhibition zones. Assays were performed for the initial $\mathrm{Et}_{2} \mathrm{O}$ (dissolved in chloroform) and $n$-butanol (dissolved in MeOH) extracts, all Sephadex LH-20 fractions of the $n$-butanol, and all reverse-phase HPLC fractions of the second active Sephadex LH-20 fraction including the baseline collection and the column washes.

\section{Acknowledgements}

This research work was financially supported by the PRIN-MIUR 2007 Project "Antitumor natural products and synthetic analogues" and the EU RTN Marie-Curie action 339 FP6, BIOCAPITAL, contract no. MRTN-CT- 2004-512301. The NMR spectra were recorded at the ICB NMR Facility, the staff of which is gratefully acknowledged. 


\section{References}

1. Urban, S.; Leone, P. A.; Caroll, A. R.; Fechner, G. A.; Smith, J; Hooper, J. N. A.; Quinn, R. J. J. Org. Chem. 1999, 64, 731.

2. Tsukamoto, S.; Tane, K.; Ohta, T.; Matsunaga S.; Fusetani, N.; Van Soest, R. W. M. J. Nat. Prod. 2001, 64, 1576.

3. Goetz, G. H.; Harrigan, G. G.; Likos, J. J.Nat. Prod. 2001, 64, 1581.

4. Aiello, A.; D’Esposito, M.; Fattorusso, E.; Menna, M.; Müller, W. E. G.; Perovic'-Ottstadt, S.; Tsuruta, H.; Gulder, T. A. M.; Bringmann, G. Tetrahedron 2005, 61, 7266.

5. Aiello, A.; D’Esposito, M.; Fattorusso, E.; Menna, M.; Müller, W. E. G.; Perovic'-Ottstadt, S.; Schröder, H. C. Bioorg. Med. Chem. 2006, 14, 17.

6. Aiello, A.; Fattorusso, E.; Giordano, A.; Menna, M.; Müller, W. E. G.; Perovic'-Ottstadt, S.; Schröder, H. C. Bioorg. Med. Chem. 2007, 15, 5877.

7. Kuramoto, M.; Miyake, N.; Ishimaru, Y.; Ono, N.; Uno, H. Org. Lett. 2008, 10, 5465.

8. Forenza, S.; Minale, L.; Riccio, R.; Fattorusso, E. J. Chem. Soc. D, Chem. Commun. 1971, 1129.

9. Garcia, E. E.; Benjamin, L. E.; Fryer, R. I. J. Chem. Soc., Chem. Commun. 1973, 78.

10. Kinnel, R. B.; Gehrken, H.-P.; Scheuer P. J. J. Am. Chem. Soc. 1993, 115, 3376.

11. Kinnel, R. B.; Gehrken, H.-P.; Swali, R.; Skoropowski, G.; Scheuer P. J. J. Org. Chem. 1998, 63, 3281.

12. Grube, A.; Köck, M. Org. Lett. 2006, 8, 4675.

13. Arndt, H.-D.; Riedrich, M. Angew. Chem. Int. Ed. 2008, 47, 4785.

14. Mourabit, A. A.; Potier, P. Eur. J. Org. Chem. 2001, 237.

15. Buchanan, M. S.; Carroll, A. R.; Addepalli, R.; Avery, V. M.; Hooper, J. N. A.; Quinn, R. J. J. Org. Chem. 2007, 72, 2309.

16. Wilson, D. M.; Puyana, M.; Fenical, W.; Pawlik, J. R. J. Chem. Ecol. 1999, 25, 2811.

17. Richelle-Maurer, E.; De Kluijver, M. J.; Feio; S.; Gaudêncio, S.; Gaspar, H., Gomez, R.;Tavares, R.; Van de Vyver, G.; Van Soest, R. W. M. Biochem. Syst. Ecol. 2003, 31, 1073.

18. Keifer, P. A.; Schwartz, R. E.; Koker, M. E. S.; Hughes Jr., R. G., Rittschof, D.; Rinehart, K. L. J. Org. Chem. 1991, 56, 2965.

19. Kato T.; Shizuri, Y.; Izumida, H.; Yokoyama, A.; Endo, M. Tetrahedron Lett. 1995, 36 , 2133

20. Kelly, S. R.; Jensen, P. R.; Henkel, T. P.; Fenical, W.; Pawlik, J. R. Aquat. Microb. Ecol. 2003, 31, 175.

21. Amade, P.; Charroin, C.; Baby, C.; Vacelet, J. Mar. Biol. 1987, 94, 271.

22. Kobayashi, J.; Ohizumi, Y.; Nakamura, H.; Hirata, Y. Experientia 1986, 42, 1176.

23. Kobayashi, H.; Kitamura, K.; Nagai, K.; Nakao, Y.; Fusetani, N.; Van Soest, R. W. M.; Matsunaga, S. Tetrahedron Lett. 2007, 48, 2127.

24. Grube, A.; Köck, M. Angew. Chem. Int. Ed. 2007, 46, 2320. 